\title{
Insiders Voices: Vocational Curriculum Pathway Implementation in Central Province of Zambia.
}

\author{
Nephat Kasebusha ${ }^{1 *}$, Martin Banda, PhD $^{2}$ \\ ${ }^{1}$ Kapiri Girls National Technical Secondary School Kapiri Mposhi \\ ${ }^{2}$ University of Edenberg Kitwe
}

*Corresponding Author: Nephat Kasebusha, Kapiri Girls National Technical Secondary School Kapiri Mposhi, Zambia

\begin{abstract}
The vocational pathway subjects were declared in 2013 and implemented in 2014. The aim was and is preparing learners with relevant knowledge, equip them with practical skills and positive attitudes towards vocational activities. Strategically to preparing learners for the challenges and opportunities of the 21 st century and respond to sustainable development goal number 1 and 4 to reduce poverty everywhere and achieve quality education and long life learning for all by 2030. The study conceptualized the voices on the effective implementation of vocational pathway subjects in schools from the system theory perspective. The school is viewed as a productive system, which receives inputs from the context and transform them into outputs. Literatures from various studies ranges from the Global, African and Zambian studies on vocational pathway subjects were consulted. The study employed both qualitative and quantitative research methods. The study utilized descriptive research design. The sample size was 241. The study showed that the vocational pathway subjects were not effectively implemented in secondary schools due to various challenges at the implementation stage. The study suggested various solutions that can make the vocational career pathway subjects be effectively implemented.
\end{abstract}

Keywords: Vocational pathway subjects, Career pathway, implementation, curriculum, secondary school, effectively implemented, ineffectively implemented, relevant skills, knowledge, self-reliance.

\section{INTRODUCTION}

\subsection{Background}

From the time Zambia got her political independence in 1964, the education system has been following the knowledge based curriculum. Shiundu and Omulando (1992) comments that no curriculum remain relevant and perfect for all ages. It must keep on changing to address the needs that emerge as society changes. This helps to construct and reconstruct the curricula to make it relevant to learners and society. The vision of Zambian education sector is that by 2030 through the competency based curriculum, learners will be expected to acquire three critical educational elements namely; worthwhile skills, appropriate and applicable knowledge which make-up competences. Competences are abilities, critical to the performance of specific tasks. To become competent at anything, a learner needs to know something about it, have the skills to apply the knowledge and have the right attitudes that ensure he or she will do it well (MOGE, 2013).

In 2013, the Zambian education curriculum was revised from knowledge based to outcome based curriculum or competency based curriculum in order to respond to the calls of the Sustainable Development Goal number four of quality education and the vision 2030. This will be achieved when learners are provided with knowledge and worthwhile practical skills. According to the Ministry of General Education (2013), the vocational curriculum was intended to meet the national educational goals whose aim is to achieve all round development of the learner through self-reliance of an individual. Zambian revised education curriculum focuses on producing a learner who will have life skills to cope with different challenges of life. The Zambian curriculum was reformed in order to prepare learners for future challenges in the rapid changing world (MOGE, 2013). The aims of the 2013 revised Zambian education curriculum are to produce self- motivated, lifelong learners, 
confident productive individuals and holistic, independent learners with values, knowledge and skills to enable them to succeed in school and in life.

\subsection{Significance of the study}

Gash (2010) states that significance of the study provides answers as to what the study will contribute. It should specifically state the value of the study. It was postulated that the study would bring to light information about the factors that contribute to the effective implementation of the Vocational career pathway subjects in order to help learners acquire knowledge and develop practical skills. The findings of the study is useful for future research on the implementation of vocational career pathway subjects. It would add knowledge to already existing body of information on vocational career pathway implementation. The data obtained from the research study is of great help to the government policy makers and curriculum implementers in supporting the successful and effective implementation of vocational career pathway subjects in senior secondary schools. Furthermore, the findings from the study would enable other organizations such as the church, NGOS, cooperating partners and other well-wishers to be aware of the support they can offer to secondary schools.

\section{LITERATURE REVIEW}

\subsection{Background}

From the time Zambia got her political independence in 1964, the education system has been following the knowledge based curriculum. Shiundu and Omulando (1992) comments that no curriculum remain relevant and perfect for all ages. It must keep on changing to address the needs that emerge as society changes. This helps to construct and reconstruct the curricula to make it relevant to learners and society. The vision of Zambian education sector is that by 2030 through the competency based curriculum, learners will be expected to acquire three critical educational elements namely; worthwhile skills, appropriate and applicable knowledge which make-up competences. Competences are abilities, critical to the performance of specific tasks. To become competent at anything, a learner needs to know something about it, have the skills to apply the knowledge and have the right attitudes that ensure he or she will do it well (MOGE, 2013).

In 2013, the Zambian education curriculum was revised from knowledge based to outcome based curriculum or competency based curriculum in order to respond to the calls of the Sustainable Development Goal number four (4) of quality education and the vision 2030. This will be achieved when learners are provided with knowledge and worthwhile practical skills. According to the Ministry of General Education (2013), the vocational curriculum was intended to meet the national educational goals whose aim is to achieve all round development of the learner through self-reliance of an individual. Zambian revised education curriculum focuses on producing a learner who will have life skills to cope with different challenges of life. The Zambian curriculum was reformed in order to prepare learners for future challenges in the rapid changing world (MOGE, 2013). The aims of the 2013 revised Zambian education curriculum are to produce self- motivated, lifelong learners, confident productive individuals and holistic, independent learners with values, knowledge and skills to enable them to succeed in school and in life.

The education curriculum is good with broad deeply rooted ideas that should be well implemented so as to achieve the goals and objectives of education to society. The Zambia's vision 2030 is a long term national development plan, which provides a strategic focus for it to become a prosperous middle income nation. To attain this vision, the role of education will be critical. Quality education will be achieved when the curriculum is effectively implemented. International Youth Foundation (2014: 37) indicates that, "education and skills training are very important and key pre-requisite elements for the creation of employment by creating skilled workforce." This starts with increasing quality education with a curriculum that offers practical and highly applicable skills. An effective curriculum is aligned to meet the prevailing labor needs of the country. For example, Zambia has many employment and business opportunities in the construction, agriculture, tourism, manufacturing, sports and mining industries, however much of the education provided continued to be academic and of little benefit to the industrial workforce. The World Bank (2013) states that the Zambian urban towns and streets are filled with thousands of jobless and highly unhappy school leavers with no survival skills. The creation of the vocational curriculum track may help to solve the challenge of unemployment in Zambia. International Youth Foundation (2014) points out that most of the available 
job opportunities in the informal and non- formal sectors require some form of practical skills. The secondary school system has to focus on providing practical education. This may help the Zambian society to believe that the aim of education is not only to be employed away from one's family community but also to be self-employed and employ others. The high unemployment coupled with flawed school curriculum is a serious time bomb in this era of rising delinquency. This state of affairs should be of worry to policy makers.

MOGE (2013) contends that there is a general consensus on the need for relevant education system for each generation. Many countries are positioning themselves to meet the demands of job market and Zambia is no exception. The vocational career pathway may help to derive the required change in order to respond to the needs of the nation and learners. This career pathway seeks to equip learners with essential competencies and skills necessary to operate a particular job successfully. It puts much emphasis on labor market by the development of innovative, creative and entrepreneurial skills. Vocational education embraces academic and vocational training. It seeks to facilitate the acquisition of skills to enable learners to be self-employed if they did not secure further formal employment. According to MOGE (2013), cognitive skills have to do with intellectual competences that have to do with the mind and reasoning abilities while the psychomotor skills are about using the body (hands and legs). The two tier system of education brings into focus four domains of skilled activities. The cognitive skills (thinking), psychomotor skills (body), reactive skills (emotions) and interactive skills (reactions), which are important in imparting knowledge, competences and attitudes. The four skills domains seek to develop technical and vocational competences among learners at the right stage of their lives and help them use such skills to earn a living, create wealth and improve lives of their communities.

Spady (2004) indicates that outcomes are high quality, culminating demonstrations of significant learning in content. For too long Zambian learners have been memorizing content, which they require to recall and produce in a test and examinations. The focus should shift to what learners can do with their knowledge and skills and use what they know to meet the goals and objectives of the educational policy. The vocational curriculum was intended to meet the national educational goal whose aim is to achieve an all-round development of the learner through self-reliance of an individual. The greatest problem that Zambia and other developing countries are facing is the provision of quality education to the citizens. Quality education is regarded as an essential requirement in all sectors of the economy. Bishop (2007) postulates that quality education exposes students to opportunities in life aimed at the preparation of the individual for the challenges and roles waiting as a member of the immediate environment. Education plays great roles in national development; it is not only welfare indicator but also a key determinant of earnings and an important exit route from poverty. The effective implementation of the educational curriculum helps to bring about an investment on human capital. Human capital is an important determinant of economic growth. Bishop (2007) argues that the capital returns increases when the level of education goes higher and individuals' benefits from the education of others. Therefore, effective implementation of the curriculum is a great strategy for quality education to facilitate and foster economic growth. The access to quality education has to be increased because of the globally competitive quality education system.

The MOE (1996:30) indicates that, "basic education aims at providing each learner with solid academic and practical foundation that will serve as the basis for a fulfilling life and that will equip each one with the pre-requisites skills and knowledge needed for a working life." Therefore, well and effective implementation of the curriculum help to prepare students for a future working life. MOE (2000:12) adds that, "the goals of basic education is to prepare students acquire a set of life skills, values, attitudes and knowledge, which will play a foundation for school leavers ability." Spady (2004) highlights that quality education enables the development of human capital respond to development demands of society. It is only when people are empowered with better education that they can respond to modern development challenges.

According to the MOGE (2013:6), "the revised curriculum intends to improve the productivity of the labor force in both formal and informal sectors with the aim of increasing the efficiency of national economy." The vocational curriculum may help to develop a society with people that will be versatile, creative, employable, entrepreneurial and productive, provide quality training for imparting appropriate vocational skills relevant to society. The Mission Statement according to the MOE (1996: 5 ) is to guide the provision of education for all Zambians so that they are able to pursue knowledge 
and skills, manifest excellence in performance and moral uprightness, defend democratic ideals, accept and value other persons on the basis of their personal religion, ethnic origin or any other discriminatory characteristics education and life skills training, building capacity for the provision of quality education. Killen (2007) argues that the education system of every country should focus on the all-round development of learners. It should aim at churning out individuals who should contribute positively towards socio-economic development. One of major tasks that education should perform in society is the preparation of youths' minds for the role and responsibilities they are expected to assume and perform when they turn into adults. Furthermore the MOGE (2013:7) indicates that the revised curriculum intends to provide skills and opportunities that will respond to Zambia's needs such as poverty reduction, improve health care and stimulate the development of quality assurance, provide access to training opportunities to all the people, acquire a culture of entrepreneurship.

\subsection{Conceptual Framework}

This study conceptualized the effective implementation of the vocational curriculum pathway from the system theory perspective, where the school is viewed as a productive system, which receive inputs from the context and transform them into outputs. The school outputs are direct products of the interaction of the resource materials, trained teachers, financial resources, infrastructures (physical facilities) such as workshops, laboratories, classrooms and the general school physical environment, tools and equipment, instructional supervision, interest groups and assessments. According to Huberman and Miles (1994) leaners outputs refer to learners' achievements or attainments. The frame work presents the physical facilities and teaching and learning resources and human resource as the inputs in the vocational curriculum implementation process. These inputs interact with the content, teaching and learning resources, assessments, monitoring and feedback and support service in order to achieve and produce the intended educational outputs namely the syllabus coverage, employability skills, lifelong skills and attitudes in learners.

The framework holds the view that the physical facilities, teaching and learning resources and human resources mutually acts together to influence the quality of vocational curriculum pathway subjects implementation. The framework views the vocational curriculum implementation as an interplay of content, teaching and learning resources, support services and monitoring and feedback activities in order to achieve the intended outputs. Therefore, the utilization of these physical facilities, learning and teaching resources and human resource in the vocational curriculum implementation process eventually determines the kind of outputs of the educational process. Each one of the factors play its own role in the process of vocational curriculum implementation in order to yield intended educational outputs. For example, the teaching and learning resources are useful in the development of instructional content, the physical facilities are important as they provide supportive environment in which learners interact with the content and the human resource implement what has been planned in the curriculum so as attain the intended outputs such as syllabus coverage, acquisition of employable skills, life- long skills, knowledge and attitudes in learners. In the conceptual framework, independent variables act as the factors that affect the acquisition of skills, knowledge, syllabus coverage and attitudes. They are viewed as inputs. While the dependent variables are employability skills, life- long skills, knowledge, syllabus coverage and attitudes. These are regarded as outputs. In line with Miles and Huberman (1994), conceptual framework shows a visual or written product that explain diagrammatically or in narrative the main things to be studied which are key factors, concepts or variables and the presumed relationship.

\subsection{Philosophical Justification of Vocationalising Education}

The idea of vocationalising education is justified by the philosophies of pragmatism, Marx's polytechnic education, pluralism. All these philosophies are with the idea of making education relevant to the needs of the society (Lauglo and Elis, 2012).

\subsection{Pragmatism}

Pragmatism epistemology underlies the ideas which hold that learning should be directly relevant to the concerns which learners have or will face in their out of school life, in their private lives and their future roles as workers and citizens (Ozmon and Craver, 2007). John Dewey, propounded the need for an experiential continuum between what learners experience at school and what they experience in society. The problems of funding and preparing for an occupation should be addressed by the school 
to make education as directly useful as possible. Pragmatist epistemology places further emphasis on utilitarian nature of vocationalising education by pointing out that secondary school education should assume a mass character in order for it to give more scope for preparation for work, citizenship and the private life. This would enable school leavers to take up responsible and functional circles in society that are so necessary for societal transformation.

\subsection{Marx's Polytechnic Education}

The other support for vocationalization of practical subjects is found in the socialist concept of polytechnic education, which is rooted in Marxist epistemology (Lauglo and Lilis, 2012). Marx held that man learn by acting on natural phenomena, transforming them while experiencing their influence. Marxist epistemology views this experience as criterion of truth. Therefore, curriculum should seek to integrate theory and practice to produce a worker-intellectual. This idea of practice is central in Marxist epistemology. While pragmatism emphasizes the value of experience and activity more generally, Marxism stresses the educative value of productive work in particular. For this reason, the concept 'education with production is an idea which has been recurring in socialist rhetoric and policy. Therefore, education and work are perceived as inseparable parts of life.

\subsection{Populism}

The populism with its ecological curriculum, aims to promote self-employment by generating economic activities in the local communities thereby reducing the rate of migration to town. The rural bias coined ruralisation of the curriculum, thereby aim to diminish the gap between urban and rural areas in a bid to transform the peasant society as well as the intervention of the public order to increase production and to furnish the people with services. Populism, therefore physically celebrates the importance of work as a source of moral fibre, self-reliance and civic virtue (Lauglo and Lilis, 2012). According to populist perspective vocational education is the answer to rural problems, to alleviate unemployment, to reorient learners' attitudes towards rural society, to halt urban migration, to transmit skills and attitudes useful in employment and as an important measure of development for youth in rural areas.

The three philosophical justifications of the benefits of vocationalising education did not indicate on how the vocational pathway subjects can be effectively implemented in order to bring out the desired results of self- reliance and employment creation. The philosophers focused much on the benefits of vocational subjects without putting into consideration on how these subjects can be effectively be implemented so as to trickle down the benefits to learners and society at large.

\subsection{Implementation of Vocational Curriculum Pathway Subjects}

The general domain regarding curriculum implementation in secondary schools has gathered significant research momentum in recent years. Studies about curriculum implementation have been conducted in various parts of the world.

\subsection{Global Studies}

Schwartzman (2006) conducted a study on the challenges of vocational education in Brazil. The study revealed that education in Brazil had changed significantly. However, it was still far from satisfactory. The public schools in poor regions, municipalities and neighborhoods tend to be of worse quality and school achievement depends on heavily on the family's economic, social and cultural background. Emenuela (2006) carried out a on the challenges of secondary vocational education in Latin America and East Asia. The findings of the study shows that financing constraints were pervasive. The enrolments increased while the implementation remained underfunded. The study by Amphiah (2002) indicates that teachers regard vocational subjects as for the academically weak learners. The study on attitudes among school administrators and teachers towards vocational subjects found that vocational subjects were rarely ranked among the best liked subjects in schools. The negative attitudes towards vocational programmes negatively affected the implementation of the subjects as the distribution of funds to it is determined by support of the school administrative system. Therefore, the challenge of lack of sufficient resources for teaching and learning emanate from the negative attitudes towards vocational subjects.

Mark(2002) did a study on factors affecting learners' performance in schools in Canada. The study found out that the learners could not improve their performance where school facilities, tools and 
equipment are not available. The hands on activities have stronger effect on knowledge and development of relevant skills. Rivikin (2005) conducted a study in the United States of America on the relationship between the availability of school facilities and learners' performance. The study revealed that the inadequate provision of physical facilities lead to poor implementation of the school curriculum. Psacharopolos (2016) found similar results that lack of school facilities such as laboratories compromise the implementation of practical subjects. The topics meant to be taught practically are taught theoretically due to lack of supporting physical facilities and equipment. This end up affecting learners' performance negatively. Fisher (2006) conducted a study in Georgina on the impact of school infrastructures on learners' attainment. The study showed that the availability of infrastructures help to improve learners' performance. Despite the political attention that is being given to vocational education, the literature on vocational education lacks agreement on the relevance and effectiveness of vocational education in developing countries. On the one extreme is the argument that disfavors vocational education. Vocationalization cannot be a remedy for uneducated unemployment. It has been noted that vocational education is deemed to failure in developing countries due to lack supporting infrastructures in developing nations.

Killen (2007) studied on challenges of vocational and technical education. The study showed that there was inadequacy provision of basic workshops, tools and equipment. Generally, there was a short supply of teaching and learning materials and basic tools by schools. Since vocational education rely on materials and tools, the short supply negatively affect the practical skills acquisition. The biggest challenge facing vocational education was how to provide quality teaching and learning programmes that ensures the development of productive and efficient workforce capable of meeting international competitiveness. Vocational education requires workshops, tools, equipment and materials for demonstrations and practical works. Similarly, Braslavsky (2002) conducted a study on challenges facing vocational and technical education in developing countries. The most critical challenges identified by this study was the rampant lack of teaching materials and workshops for both teachers and learners to conduct practical activities for leaners to acquire relevant knowledge and skills. Generally, the study showed that schools in developing countries had acute shortage of materials and workshops to conduct practicals and in the end, this compromised the quality of the learners. Sherry (2013) studied on challenges facing Vocational and Technical education in Korea. The study reported that vocational education in Korea was bedeviled with problems. Some of these problems were lack of facilities and materials for teaching and learning, mismatch between acquired skills and market needs.

Claudis (2015) carried out a comparable study on barriers to accessing skills development and employment for the youth in Argentina and South Africa. The study shows that South Africa made significant gains and progress than Argentina in overcoming the skills development. Despite the progress, low levels of skills among the majority learners of the disadvantaged were high among the learners and youth. Alexandre (2015) conducted a study also on challenges that surrounds vocational education in India and Brazil. In both India and Brazil, vocational education has moved up the political agenda, it is seen as a key mechanism in facilitating entry into the labour market. However, the study indicate that there were many challenges in India surrounding vocational education, these includes issues of quality of delivery, shortage of vocational subject teachers and inadequate infrastructures. The study show that there some similarities in the problems and challenges faced in India and Brazil. Introducing vocational education is not without its challenges where secondary schools are preparing leaners for entry into tertiary and labour market. Vocational education requires greater investment than academic education due to necessity of specialized facilities, equipment and materials for practical implementation.

Cash (2003) found out that physical facilities including classrooms and furniture have significant relationship with the performance of learners. The study reported that learners in undesirable physical environment do not concentrate during the teaching and learning process, which eventually leads to poor curriculum implementation in schools. The learners require comfortable and spacious sitting and working facilities to enable them efficiently and effectively engage in the learning process, which lead to high performance. The school environment includes learning infrastructure such as classrooms, laboratories, libraries, school halls and fields. Fisher (2006) conducted a research on the impact of school infrastructures on student outcomes and behavior in Georgia and established that learners' performance improves with improved building conditions such as lighting levels, air quality and temperatures. The study revealed that school building had an impact on the mental development of 
learners and that schools that are properly built are attractive to motivates them. Mark (2002) in a study of factors affecting learners performance in schools in Canada maintained that one cannot expect level of student academic performance where school building are poorly located and substandard. The study concluded that well planned structures and health environments are important components of successful implementation of the vocational curriculum in schools. Some physical facilities in schools are fundamental factors for better learning environment, achievements and outcome of the students. School infrastructure provide and maintain cleanness, safety and it enables a learning environment to be conducive and creative to learners. This encourages them to perceive high achievements and outcome.

In order for the curriculum to be implemented in an effective manner, the schools should have the needed facilities to support it. The school facilities are significant in implementing the curriculum. These facilities have direct positive and negative effects on teacher and learner confidence. Rivkin (2005) conducted a study in the United States of America to establish the convenience of the facilities to learners and noted that there is a strong relationship between the availability of school facilities and learners' performance. The study concluded that inadequate provision of school physical facilities in schools lead to ineffective implementation of the curriculum and low acquisition of skills among learners.

Leeper (2008) carried out a study on the importance of school infrastructure in implementing the curriculum and found out that the availability of physical facilities have a significant positive role on the performance of the students and their attainment. When learners are exposed to laboratory activities, they observe, taste, listen and touch to learn about their environments much easier. The hands on learning increase leaners' knowledge and skills development. Cronin (2012) argued that for learners, hands-on type of learning has a stronger and positive effect on knowledge and skills acquisition than on attitude in institutions well invested with physical facilities.

\subsection{African Studies}

The study by Achola (2009) revealed that the introduction of vocational subjects tend not to lead to significant skill acquisition. In most schools it was poorly implemented as a result it failed to achieve the objectives of providing skills for the development of the formal and informal sector. The objectives were rarely achieved even though worldwide variety of approaches to achieve the objectives had been developed and tried. Mucavele (2010) agreed with Achola (2009) that no meaningful teaching process can be provided without resources and facilities. These factors significantly changes the whole picture of teaching vocational subjects. Study by Weeks (2002) showed that vocational education is expensive in terms of both buildings, equipment and teachers. The study reported that most schools that tried to vocationalise were poorly constructed, equipped and staffed for vocationalization. The employers tend to look down on the products of vocational education as inferior, they prefer to train themselves in the job. King (2008) found the same results with Weeks (2002) that the major problems found against the successful implementation of vocational subjects was inadequate financing for building and equipment. This resulted in vocational education assuming barefoot approach to its implementation.

Lauglo (2004) found out that vocational subjects have complex tooling up, the setting up and maintenance of facilities, equipment and tools, the supply of materials and consumables were not met in a minimally adequate way, hence vocational subjects had suffered from run-down facilities. Compared to academic subjects, most vocational practical subjects had considerably higher unit of costs due to facilities, equipment, materials, and consumables. The study by Lauglo (2004) revealed that vocational subjects lack attractiveness for learners and teachers as their morale was too low. The study further reported that the implementation of vocational subjects had some flaws in the absence of minimally adequate workshops, equipment, consumables, vocational subjects easily degenerate into being taught theoretically with inadequate attention to practical skills learning. Onyene (2007) conducted a study in Nigeria on vocational education and found out that it was important for the purpose of national development and self-employment but was more theory than practical aspect. The study reported that the failure to meet with the national development needs was attributed to theory than practicals in Nigeria as most leaners were mostly exposed to theory without practicals.

King (2008) conducted a study on the successful implementation of vocational subjects. The findings were that the implementation faced the challenge of inadequacy of financing for buildings, equipment 
and teachers. These challenges were found militating against the successful implementation of the subjects. It is well known fact that vocational subjects requires adequate facilities for successful implementation. Without adequate facilities, learners will not be able to acquire the expected skills and their education would be considered a waste. The vocational education is efficient in proportion when the environment in which learners are taught is a replica of the environment in which they must subsequently work. Odu (2010) comments that effective vocational learning could only be given where the training jobs are carried on the same way with the same operations, same tools and same machines as in the occupation itself. Changwila (2016) carried a study in Kenya on challenges facing effective implementation of vocational subjects. The study revealed that both teachers and learners identified challenges belied to have hindered effective implementation of the subjects. The major challenge was inadequacy of resources or materials for the successful implementation of vocational subjects. These challenges limited the number of practical sessions to be conducted, thereby denying the learners experiential learning.

Odu (2010) carried out a research on the challenges against effective vocationalization of secondary education in Nigeria. The study identified inadequate facilities and misconception of the nature of vocational education hinders effective vocationalization of secondary education in Nigeria. The study by Odu (2010) also pointed out that many administrators of the programme were not trained in vocational education, hence they do not seem to understand the needs of the programme when it comes to distribution of funds. This explained why vocational subjects were grossly underfunded. The underfunding in turns affects the supply of modern facilities and equipment needed for vocational education. Emertarom (2003) affirmed that successful implementation of vocational subjects that learners receive bear direct relevance to the availability and lack of physical facilities and overall atmosphere in which learning take place. Nwagu (2004) assert that school facilities can be said to be the physical and spartial enablers of teaching and learning which increases the production and attainment of desired results. Overbaugh (2010) found out that facilities were not provided adequately, the implementation of vocational was not successfully implemented. Ehiametalon (2011) argued that school facilities are the operation inputs of every instructional programme

Onyeachu (2006) noted that no organization function effectively without funds. In his study, he found out that funds allocated to Nigerian vocational education were inadequate, hence the ineffective implementation of vocational subjects in schools. This caused stagnation and decay of vocational subjects. The shortfalls and inadequacies in education funding manifest in the classroom, equipped workshops, libraries and laboratories. The study found that the condition under which vocational education was imparted was poor. Most schools lacked relevant equipment for teaching and learning practicals, lack of workshop and facilities had ill equipped laboratories. This had been attributed to low level of funding vocational and technical education, which had been a problem in the implementation of vocational subjects in secondary schools. The findings of Makaye (2013) pointed out that most of the learners were still in their tentative choice period and were not serious about their career choices. This meant that vocational subjects were taught like academic subjects and not really for the purpose of making learners acquire certain skills due to poor facilities and shortage of resources. The disparity between what was expected and the reality constituted a major barrier to innovation. The schools should strive to reproduce adult situations in the classroom in order to prepare learners for adult life. There is great need to make them learn by doing and introducing hands on activities in schools.

Kathrin (2008) conducted a study South Africa on the cost and benefits of vocational education and training to learners. The findings of the research were that vocational education improves earnings, employment chances, mobility, capacity for life- long learning, measures of working of working conditions and job satisfaction. Employer's benefits arise from apprentice productivity increases. The state yield net benefits both in terms of social rents( both individual and public costs plus positive externalities from increased productivity due to better education)and in fiscal terms education expenses verses increase in tax income from higher earnings from better educated individuals. The study focused on the cost and benefits of vocational education, therefore the study by Kathrin provides the basis for the current study. Zinganyu (2010) carried out a research on factors affecting curriculum implementation in secondary schools. Though the study did not focus on vocational curriculum implementation, it helps the current study to establish from the Zambian perspectives the factors contributing to effective implementation of the vocational curriculum path way in secondary 
schools. Kanorio (2016) also conducted a study on curriculum implementation and strategies for improved learning outcomes in primary schools in Kenya. This study was confined to primary school curriculum, however, it was not specific to which curriculum track it focused. Therefore, the study by Kanorio provides the basis for the current researcher to study on effective implementation of vocational curriculum in junior secondary school.

\subsection{Zambian Studies}

Kalisto and Sanny (2015) carried out a study on the factors that affect the implementation of localized curriculum in Basic schools. The study focused on factors that affect the implementation of localized curriculum in Basic schools. Therefore, this study looked into the implementation of vocational curriculum pathway subjects in senior secondary schools. Mwila (2016) studied on education and skills development; examining the effectiveness of Technical, Vocational and Entrepreneurship at the tertiary level of education in Solwezi District. The findings of this study revealed that training was confronted with infrastructural challenges such as outdated workshops, tools, shortages of workshop and classroom accommodation, poor library facilities and poor internet connectivity. These were established to have an effect on skills acquisition because the equipment at the institutions did not match modern equipment in industries. There is no study on the implementation of vocational education at the senior secondary school level, hence the study. Chanda (2016) conducted a study on the perceptions of stakeholders towards vocational and academic learning pathways in Kafue District. The study revealed that the perceptions of the stakeholders towards the vocational pathway subjects are good despite the fact that the school had to choose to take on certain learning pathways based on the availability of suitable infrastructure and equipment in the school. Therefore, the infrastructure and equipment determine the vocational subject the school to adopt for learners. The study focused on the perception of stakeholders on vocational and academic pathways, this study therefore tried to investigate on how the vocational pathway subjects are being implemented in secondary schools.

Kapuka (2017) conducted a study on the vocationalization policy in Zambia's secondary education sector. The study focused on vocationalization policy of secondary schools. In order to reduce the gap, the current study tried to find out how the vocational pathway subjects are implemented in senior secondary schools. Kapuka (2017) commented that vocational programmes are resource intensive and their relative success depends on the amount of investment countries willing to put in their education system. Without the adequate resources, the teaching of practical subjects would be as theoretical as academic subjects. The secondary schools in Zambia are not ready for vocationalization. The lack of facilities would negatively affect quality of education in the vocational track as rote learning as opposed to actual performance would likely to result. The study therefore tried to find out how vocational pathway subjects are being implemented in the midst of challenges stated by Kapuka.

Kaluba (2006) conducted a study on the challenges of schooling and the paradox of the private school solutions. The study found out that the Zambian schools experience shortage of physical facilities such as classrooms, which hinders access the education services to learners from the poor background. In addition, Mwanza (2015) conducted a study on problems and challenges in achieving the global education goals. The findings were that the majority of schools' performance was very poor due to lack of teaching and learning materials and dilapidated and inadequate infrastructure, inadequate and poor sanitary conditions. Zulu (2009) conducted a study on the impact of school facilities on academic performance. The study explored the possible relationship between the school facility conditions and learners' achievement. The study reported that the condition of the school facilities such as the classrooms' lighting system and ventilation affect the healthy and learning of the students. Hatiya (2016) also carried out a study on the relationship among school's infrastructure facilities and learners' outcomes. The study lamented that good infrastructure facilities always support the education enterprise. The good learning environment are important for student academic achievement. The schools with better building conditions have lower rate of suspension.

\section{Methodology}

The mixed research paradigm (qualitative and quantitative research methods) was used to collect, integrate and analyze data. These methods helped to maximize the strength and minimized the limitations or weaknesses of each other. Therefore complemented each other during the study, hence data collected was reliable. The descriptive research design was used to integrate various components 
of the study in a coherent and logical manner in order to effectively address the research problem. The descriptive research design was used to collect the experiences, feelings, views, opinions and thoughts of the respondents on the implementation of the vocational pathway subjects in secondary schools.

The sample population were all head teachers, heads of department, heads of sections, vocational subject teachers and vocational subject learners of the five (5) selected secondary schools. The sample size was 241 respondents. Purposive sampling was used to select all head teachers, heads of departments, heads of sections, vocational subjects teachers and vocational subjects learners while the systematic random sampling with the interval of three (3) was used to select learners to constitute the sample for the study. The simple random sampling was used to select five (5) schools from the urban secondary schools by using the lottery method.

The questionnaire was used as both an instrument and method of collecting quantitative data. They helped to collect data from the vast areas, uphold respondents' confidentiality and enabled respondents express their views freely. The interview guide was used as an instrument to collect qualitative data while the interview was used as a method. The interview method enabled the researchers to test information from respondents by cross examination, hence detailed and reliable data was obtained.

\section{RESEARCH FINDINGS AND DISCUSSION}

\subsection{Implementation of vocational pathway subjects in secondary schools.}

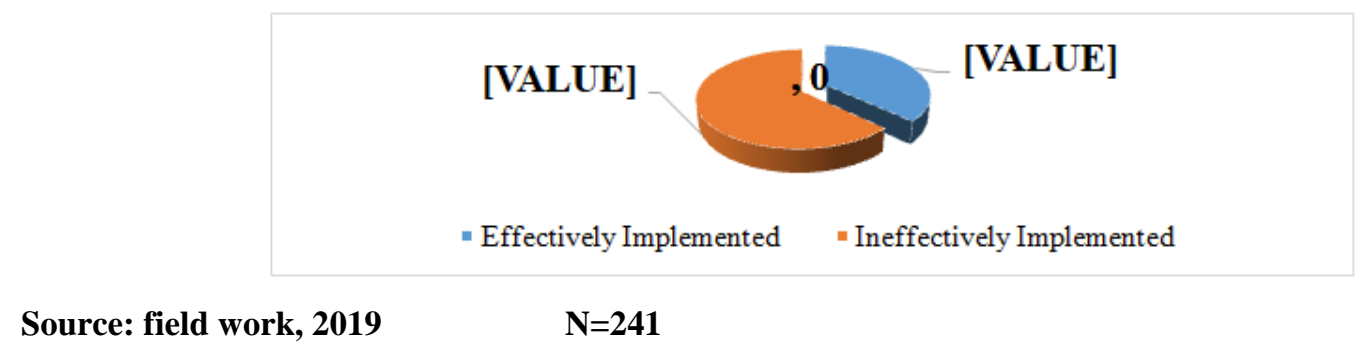

Figure1. Implementation of vocational pathway subjects in secondary schools

The study revealed that one hundred fifty two (152) representing $63 \%$ of the respondents reported that the vocational subjects were not effectively implemented due to lack of materials, facilities and equipment that could support the practical implementation. The findings of the study revealed that the vocational pathway subjects are not effectively implemented due to lack of materials, facilities and equipment that could support the practical implementation. Psacharopolos (2007) pointed out that lack of physical facilities in schools compromises the implementation of the practical subjects. This therefore deny learners with experiential type of learning and only exposed to theoretical learning.

The learners were exposed more to theory rather than to experiential learning which requires them to practice what they learn from theory. The way the vocational pathway subjects are taught is not different from the way learners were taught in the previous curriculum before 2013. This is because the practical aspect of vocational subjects is not paid much attention to. The study findings of this research reported that the introduction of vocational pathway subjects in the school curriculum tended not to lead to significant practical skills acquisition. The ineffective implementation of the vocational curriculum pathway subjects is associated with insufficient materials and physical facilities that could help learners acquire practical skills. It was noted that the ineffective implementation of vocational subjects in schools was determined by the lack and inadequate of resource materials and facilities that could support the practical teaching and learning of vocational subjects in schools. The study therefore support Psacharopolos (2016) who commented that vocational education is deemed to failure in developing countries. The schools fail to prepare learners develop and produce the desired results because schools were not supplied with adequate and appropriate materials for teachers and learners to play their role in a satisfactory manner. The implementation of the vocational pathway subjects requires the availability of materials that include course books and teachers' guides. These materials play an important role in implementing these subjects in schools because both teachers and learners are required to study the course books in order for them to apply the information or knowledge to demonstrate into practice what they read. 
When learners are exposed to laboratory activities, they observe, taste and touch in order to learn about the environment much easier. The hands on learning increase learners' knowledge and skills development. The physical facilities such as laboratories, workshops and sports infrastructural facilities play important role in implementing vocational subjects because the environment in which teaching and learning take place should depict the environment in which the occupational activities will take place after the learning program. This can enable the effective implementation of these subjects in schools. The implementation of the vocational pathway subjects had not helped to improve learners' performance because these subjects were taught just like academic subjects of the school curriculum and not for the purpose of helping learners acquire the expected practical and desired skills. There was a disparity between the skills the learners are expected to develop and the reality in school which constitute a major barrier to practical skills acquisition as it lack guidance for the curriculum to be implemented in an effective manner, schools should have the needed facilities to support it. The vocational pathway subject implementation had not yet yielded its main objectives because learners were still taught just like any other academic subject due to lack and inadequacy of the much needed resource materials and physical facilities to support its effective implementation and enhance acquisition of practical skills.

\subsection{Improvement of learners' performance}

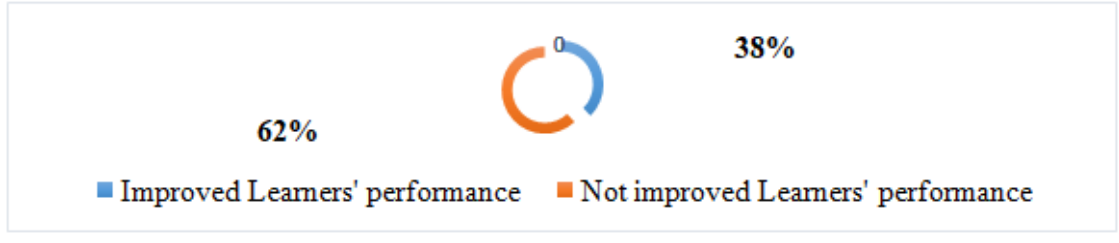

Source: Field Work, 2019

Figure2. Improvement of learners' performance

$$
\mathbf{N}=\mathbf{2 4 1}
$$

The study showed that hundred forty nine (149) out of 241 representing $62 \%$ of the informants indicated that the vocational career pathway subjects has not helped to improve the learners' performance. The majority of the respondents reported that these subjects were taught just like academic subjects of the school curriculum and not for the purpose of helping learners acquire the expected practical and desired skills.

The vocational career pathway subjects has not helped to improve the learners' performance. The majority of the respondents reported that these subjects were taught just like academic subjects of the school curriculum and not for the purpose of helping learners acquire the expected practical and desired skills. The implementation should intend to build knowledge, skills, attitudes and values that the learner can use in adult and daily life. It should be all about what the learner can do practically but not the quantity of theoretical knowledge that the learner memorizes. The disparity between the skills the learners are expected to develop and the reality in school constitute a major barrier to practical skills acquisition.

The implementation of vocational career pathway subjects had scored low success to learners. It had not shaped the tasks and the expected practical work for the greater achievement with high number of respondents indicating that the implementation of the vocational career pathway subjects had failed to improve learners' performance. The implementation of vocational subjects in secondary schools had not improved learners' performance as it was still taught just like academic subjects of the school curriculum. It is for this reason that the implementation of vocational subjects only impart knowledge and lack hands on activities. In order for learners to improve their performance, learning should take place in a conducive environment, they should be able to see and touch the vocational tools, equipment and other materials and also taste some of the consumable products they come up with unlike learning from abstract. This can enable them comprehend properly and evaluate their understanding of the learnt content in an effective manner.

\subsection{Challenges hindering the effective implementation of vocational career pathway subjects}




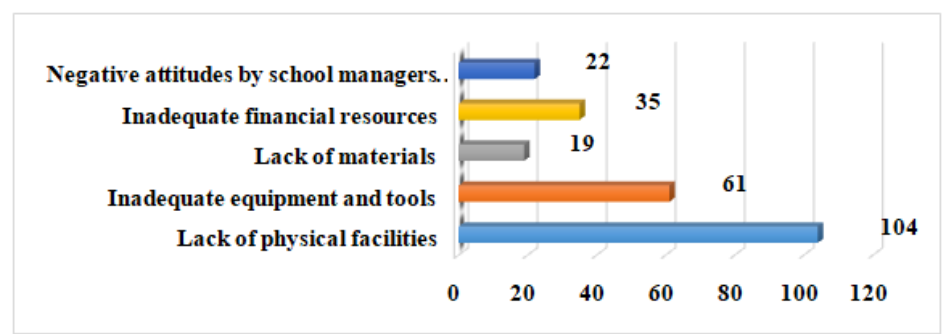

Source: Field Work, 2019

$$
\mathbf{N}=\mathbf{2 4 1}
$$

Figure3. Challenges hindering the effective implementation of vocational career pathway subjects

The findings of the study show that schools lack physical facilities such as the swimming pools, workshops, laboratories, libraries. These factors hinder the effective implementation of the vocational subjects as a result vocational subjects are taught as academic subjects without equipment and facilities that could promote the practical aspect of these subjects.

Furthermore, the study reported that physical facilities were the operational inputs of the implementation of the vocational career pathway subjects in secondary schools. The successful implementation of the vocational subjects that learners receive bear direct relevance and be anchored on the availability of physical facilities and the overall atmosphere in which the learning takes place. These facilities enables the effective implementation of vocational subjects in schools for effective teaching and learning process which increases the production and attainment of the desired objectives.

The study further report that secondary schools do not have equipment, tools, resource materials and consumables for the appropriate practical subjects. There are no such requirements for vocational subjects in schools, hence failing to effectively implement and achieve the objectives of vocational subjects to make learners develop the practical vocational skills. The secondary schools were not ready and fully prepared to implement the vocational pathway subjects in an effective and successful manner. The study brought out to light that there are some flaws in the implementation of vocational subjects in schools. The study revealed that the implementation of the vocational pathway subjects failed to realize its intended objectives of preparing learners with knowledge and practical skills amid the limited infrastructural facilities, resource materials, equipment, tools and consumables. Such challenges in the implementation of vocational subjects hinder learners to smoothly acquire both knowledge and skills.

The study showed that some of the school managers where not trained in vocational education and that they did not seem to understand the need for vocational career pathway subjects implementation in schools when it comes to distribution of financial resources. Most of the respondents reported that the school managers had negative attitudes towards vocational subjects. This explains why the vocational subjects remain under funded and therefore the negative attitudes towards vocational subjects affect the procurement and construction of modern equipment and infrastructures for vocational subjects to be taught well in schools.

\subsection{Solutions on Challenges That Hinder the Effective Implementation of the Vocational Career Pathway Subjects.}

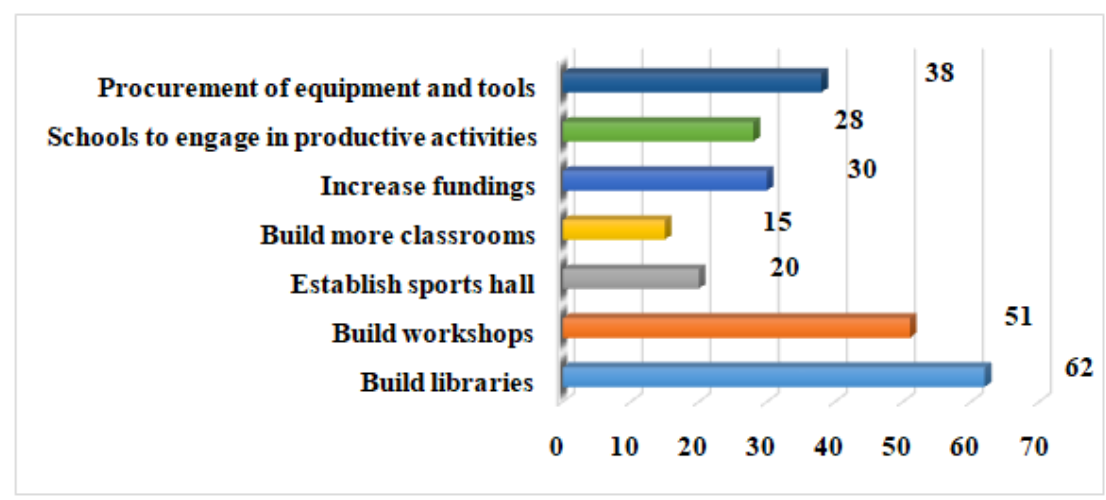

Source: Field Work, 2019

$\mathbf{N}=\mathbf{2 4 1}$ 
Figure4. Solutions on challenges that hinder the effective implementation of the vocational career pathway subjects

In order to effectively implement vocational subjects for learners to improve their performance, learning should take place in a conducive environment, they should be able to see and touch the vocational tools, equipment, also taste some of the consumable products they come up with unlike learning from abstract. This can enable them comprehend properly and evaluate their understanding of the learnt content in an effective manner.

The flaws in the implementation of vocational career pathway subjects were identified. The respondents suggested that more infrastructure or physical facilities that includes workshops, laboratories specific for each vocational subject to be built to support the practical activities and enhance effective implementation. The sports hall, proper playing grounds and swimming pools to be put in place for the effective implementation of the subjects. Physical facilities have to be put in place for the successful implementation of vocational subjects. Teachers can only implement these subjects more effectively if the physical facilities are available. This can help learners acquire both knowledge and relevant skills. The schools should engage into productive activities such as pastoral and arable farming in order to raise some funds that could help the departments to procure tools, equipment, consumables and materials needed for practical activities to enhance effective implementation of vocational pathway subjects in schools. In order to effectively implement and support the practical aspect of the vocational career pathway subjects, schools should put in place tools and equipment for the effective implementation. The learners need to see and touch what they are learning, this can ensure that they are exposed to the experiential type of learning rather than theory.

\section{CONClusion}

The study found out that the vocational pathway subjects were not effectively and successfully implemented. For the vocational career pathway subjects to be well implemented and help learners improve their performance learners should interact with materials, tools and equipment used for them to develop the psycho motor and cognitive skills which requires practical learning. When learners are exposed to theoretical learning, they are denied with the practical aspects of vocational subjects, hence the implementation of vocational subjects had not helped learners with practical skills. The vocational career pathway subjects demands learners to apply their sense of sight, touch and taste for them to learn in an effective way. They should be able to see, touch and in some situations taste what they come up with after learning. The learners have to actively participate during the teaching and learning process and this can only happen if the ratio of the materials, tools, equipment and infrastructural facilities match with the number of learners taking vocational subjects.

\section{REFERENCES}

[1] Shiundu, J, S and Omulando, S. (1992). Curriculum Theory and Practice. Nairobi: Oxford University.

[2] Ministry of Education, Science, Vocational Training and Early Education (2013). Zambia Education Curriculum Framework 2013.Lusaka: CDC.

[3] Spady, W, G. (2004). Outcome Based Educational Critical Issues and answers. Arlington: American Association of School Administrators. Volume 58 (10), 98-105

[4] Bishop, G. (2007). Alternative Strategies for Education ( $3^{\text {rd }}$ Edition). London and Basing Stoke: Macmillan Education Limited.

[5] Ministry of Education (1996). Educating Our Future: National Policy on Education. Lusaka: CDC

[6] Schwartzman, E. (2006). Challenges of vocational education in Brazil. 20(5), 60-65

[7] Emenuela, (2006). Challenges of secondary vocational education in Latin America and Asia.

[8] Amphiah, P. (2002). Attitude of teachers and learners towards vocational education in schools.

[9] Mark, K. (2002). Vocationalization of Secondary Education: Kenyans case study. Nairobi: Regional Vocational Skills Development. St. Pauls University: Nairobi

[10] Psacharopolos, G. (2016). Education for Development: An Analysis of Investment Choices. New York, Oxford University Press.

[11] Fisher, M. (2006). Impacts of school infrastructure on learners' attainment.

[12] Braslavsky, C. (2002). The New century change: New challenges and curriculum responses. COSBSE Internal Conference: New Delhi. 
[13] Shirley, M, H and Leslie, H, A. (2016). Effective Curriculum Implementation: Some Promising New Insights: The Elementary School journal, volume 87(1) page 96-98.

[14] Claudis (2015). Barriers to accessing skills development and employment in Argentina and South Africa.

[15] Alexander, T. (2015). Challenges surrounding vocational education in India and Brazil.

[16] Cash, C. (2003). A study of the relationship between school building conditions and student achievement and behavior. Blacksburg: Virginia polytechnic institute and state university.

[17] Leeper, H. (2008). Importance of school infrastructure in implementing the curriculum.

[18] Cronin, J. (2012). Hands on learning. New South Wales: University of Newcastle.

[19] Weeks, S, G. (2005). Vocationalization of Secondary Education Revised. Amsterdam: Springer Netherland.

[20] King, M. (2008). Problems militating against the successful implementation of vocational subjects.

[21] Lauglo, J.etal. (2012). Vocationalized Secondary Education Revised. Washington: World Bank.

[22] Onyene, K. (2007). Vocational Education for self - employment. 6 (4), 75-85.

[23] Odu, J. (2010). Challenges against effective vocationalization of secondary education in Nigeria. Lagos: Lagos University

[24] Changwila, P. (2016). Challenges facing effective implementation of artisan and vocational subjects.

[25] Ehiametalon, P. (2011). Operational inputs of vocational education

[26] Onyeachu, D. (2006). Can an organization function effectively without financial resources?

[27] Kathrine, P. (2008). Perception of vocationalising secondary education. Unpublished Master Thesis: Hopkins University Press.

[28] Zinganyu (2010). Factors Affecting Curriculum Implementation in Secondary Schools.

[29] Kalisto and Sanny (2015). Factors affecting the Implementation of Localized Curriculum in Basic Schools in Zambia.

[30] Mwila, P. (2016) Education and skills development: Examining the Effectiveness of Technical, Vocational and Entrepreneurship in Solwezi District. Unpublished: CBU

[31] Chanda, B. (2016). The perception of stakeholders towards vocational and academic learning pathways.

[32] Kakupa, P. (2017). The Vocationalization Policy in Zambia’s Secondary Education: A Critical Analysis. Lusaka: UNZA.

[33] Zulu, M. (2009). Impacts of school facilities on academic and performance. Lusaka: UNZA

[34] Hatiya, B. (2016). Relationship among schools' infrastructural facilities and learners' outcomes. Lusaka: UNZA

[35] Nwagu, H. (2004). The successful implementation of vocational education in Ghana.

[36] Ozmon, O, H and Craver, S, M. (2007). Philosophical Foundation of Education. Columbus: Merrill Publishing Company.

Citation: Nephat Kasebusha, Martin Banda. " Insiders Voices: Vocational Curriculum Pathway Implementation in Central Province of Zambia" International Journal of Humanities Social Sciences and Education (IJHSSE), vol 8, no. 9, 2021, pp. 57-60. doi: https://doi.org/10.20431/2349- 0381.0809006.

Copyright: (C) 2021 Authors. This is an open-access article distributed under the terms of the Creative Commons Attribution License, which permits unrestricted use, distribution, and reproduction in any medium, provided the original author and source are credited. 